follows: First stage, four days; second stage, two days; third stage, three days; fourth stage, four days, and fifth stage, five days. Total, eighteen days.

The same insect in New York, as has been determined by Slingerland, requires from thirty to thirty-three days for its nymphal development. There is then a difference of two weeks in the time of development of the grape leaf-hopper in New York and that of the same insect in California. This difference is generally attributed to climate, although there is little difference between the climate of upper San Joaquin Valley in California in June and July and that of New York in the same months.

During the last week in June the hoppers, arising from the eggs of the over-wintering hoppers laid in May, begin egg laying, which is continued through July and a part of August. The incubation period was noted for a hundred or more eggs and they all hatched in from eight to twelve days. This is a shorter period than was required for the eggs to hatch in May from the over-wintering insects, and may be due to the difference in temperature.

A number of hoppers were confined in individual breeding cages on the leaves of the grape, and the number of eggs laid varied from forty to one hundred and twenty-one, distributed over a period of from three to seven weeks.

Hoppers hatching from these eggs remain on the vine until the leaves fall, when they attack their winter food plants, which include a large number of plants that may be growing in the vineyard or vicinity. These attack the vine in the spring, begin egg laying in May, and die off in July, making the length of the life cycle approximately one year. The spring brood hatching in May lives until about August or September, thus completing the life cycle in three or four months. There are thus two broods of the grape leaf-hopper in California, and, at least during the past year, there was no indication of a third brood.

\title{
NOTES OF THE SEASON
}

\section{By H. A. Gossand, Wooster, Ohio}

The season opened with a noteworthy weather condition that seems to have had a perceptible effect on the development of San Jose scale. March 19 the mereury rose to $68^{\circ}$ at Wooster, and the following maximum temperatures were recorded at this place during the next two weeks : 
March $19,68^{\circ} ; 20,67^{\circ} ; 21,67^{\circ} ; 22,82^{\circ} ; 23,79^{\circ} ; 24,74^{\circ} ; 25,67^{\circ}$; $26,70^{\circ} ; 27,68^{\circ} ; 28,67^{\circ} ; 29,77^{\circ} ; 30,67^{\circ} ; 31,46^{\circ}$.

April 2, the mercury was down to $15^{\circ}$, and with the exception of seven nights, descended below freezing each night, until the 28th, when a warmer period commenced. However, the mercury dropped to the freezing point, or below it, nine nights in May, the last freezing record being on the 28th. Unfortunately, no direct observations were made which definitely proved this weather condition to have been adverse to the scale, but for some reason the scale has not been very much in evidence the past summer in many orchards that promised a year earlier to develop severe infestation in the normal course of events. Because of this phenomenon, I have not felt warranted in drawing conclusions regarding the effectiveness of one of the proprietary sprays which I undertook to test. The most plausible explanation occurring to me to account for this condition, is to suppose that the extended warm period in Mrarch started the dormant scales into activity, and that the cold freezing weather of April, following this warm period, proved fatal to them.

Some districts in which the scale has been controlled for three or four years with lime-sulphur spray, but were originally badly infested, are now seriously attacked and threatened with destruction by the bark borer, Scolytus rugulosus. I saw one orchard of young trees four or five years old which had never been very scaly, that was being badly attacked by these borers, which had migrated from a nearby apple orchard that had been destroyed by scale. This orchard seemed a good illustration of this insect's disposition to attack healthy trees when its numbers have outrun the supply of available weakened trees. As a trial application, I recommended to several correspondents to boil a thick lime-sulphur wash, using 20 pounds of sulphur and 30 pounds of lime, and add to each 50 gallons of this mixture 3 pounds of arsenate of lead (or 1 pound of paris green) and 6 to 10 pounds of fish-oil soap. This application was applied to the trunks and larger limbs with a spray pump or brush. Some of the parties who used it report seeming benefit, but I have not yet had an opportunity to make personal inspection of results, and shall not feel warranted in drawing any conclusions until the test is extended over several seasons. One orchardist painted the trumks and limbs of his trees in early spring with Carbolineum avenarius and the benefit against the borers was apparent. I inspected the trees in early July and, at that date, no great amount of injury to the trees from the application was perceptible, the counterbalancing benefits seeming to entirely outweigh the attending damage. 
The spring opened very late, so that the first spraying for codling moth fell about the first of June in northern Ohio. This period was very wet and quite cool. For test work, I made use of a ten-acre orchard located about ten miles from the shore of Lake Erie, and hence not damaged much by frost. One half of this orehard consisted of Baldwins and the other half of Ben Davis. I tested the coarse, driving spray, as used in the western arid states, by enlarging the orifices in Vermorel nozzles, and also used the medium caps for comparison. Three pounds of arsenate of lead were used in 50 gallons of Bordeanx-the Bordeaux formula being 3 pounds of copper sulphate and 6 pounds of lime. The trees averaged 20 feet, or more, in height, and had a corresponding spread of top. One plot was treated with one third pound of paris green to 50 gallons of Bordeaux. About one gallon of soft home-made soap was added to each 50 gallons of spray for most of the plots. One plot had 2 pounds of copper sulphate and 1 pound of iron sulphate instead of the regular Bordeaux formula. About 100 pounds pressure was maintained by the pump. For the purpose of better directing the spray, two small pieces of three-fourths inch gaspipe, about 4 inches long, were threaded at each end. and after being bent about 25 or 30 degrees from the horizontal, me was attached to the end of each rod by means of a gas coupling, and the nozzles were then attached to the bent pipes. The spray was directed downward and inward and was used until the trees dripped. On trees 20 to 25 feet high, with corresponding spread of top, from 7 to 8 gallons of spray were used. The second spraying was made abont 10 days after the first, and in the same proportions, only the copper sulphate was reduced to 2 pounds for 50 gallons of spray. Not more than one half as much spray was used in this application as in the first spraying. The third spraying was given to part of the orchard about the middle of July. Arsenate of lead alone was used for the July application, the Bordeaux being omitted. Not more than three or four gallons of spray were used on the largest trees for this application. As the full results of the test will soon appear as a Station publication, I will not enter into further details, but state results and conclusions. Over $90 \%$ of the apples on trees sprayed three times were free from worms. A record was kept of the dropped apples under certain trees beginning with the 30th of July. The following are some of the figures:

One tree sprayed twice, once just after blooming and again ten days later, has the following record: Sound apples dropped from the middle of July until harvest. 319 ; wormy drops from middle of July until harvest, 23; drops marked by curculio during the season, 8; 
sound apples picked for harvest, 4,477; wormy apples picked for harvest, 14; marked by curculio at harvest picking, 21. Thus $98.67 \%$ were untouched by either codling worm or curculio; $99.25 \%$ were untouched by codling worm, and $99.69 \%$ were free from codling worm at harvest time. An unsprayed check tree, with a far better record than some others for sound fruit, yielded at the harvest 1,670 sound apples, 347 wormy ones, and 210 marked by curculio. Some of the wormy apples were also marked by curculio, which are not shown in this enumeration. Since the middle of July, this tree dropped 221 sound apples, 339 wormy ones and 48 marked by curculio. The season's yield, drops and harvest, gave 25.62\% damaged by codling worm and eurculio combined; $19 \%$ by codling worm alone, and $20.77 \%$ were wormy at picking time.

I decided that ordinary Vermorel nozzles with medium caps gave the best spray at 100 pounds pressure, and that the little crooks were of decided advantage in directing the spray; that three sprayings gave better results than two; that the first application just after blooming should be heavy to secure immunity from worm attack; that in cold, wet seasons, such as the past spring, considerable russeting follows a heavy spraying; that less russeting occurs on fruit sprayed when it is a week or ten days old than when it is younger; that russeting would probably be reduced by omitting Bordeaux from the first application, using instead arsenate of lead with lime added, but this question needs further testing; that an application for the second brood should be made by July 15th, or earlier in northern Ohio; that soap, or other stickers, do not appreciably enhance the value of these sprays when used on apples; that at least one pound of iron sulphate can replace one pound of copper sulphate in a 3-6-50 Bordeaux formula without injury to foliage or fruit, but $I$ have not yet decided as to whether this mixture is an improvement on the ordinary Bordeaux.

The variegated cutworm, Peridroma saucia, was quite destructive in some localities, and if conditions are not unfavorable for its development, it will probably do a large amount of damage the coming year, for it is very plentiful over all northern Ohio. It attracted special notice at Sandusky, where it had attacked gardens, lawns and greenhouse products.

The radish maggott, Pegomyia brassica, was not so destructive as in some former years. I have not made very satisfactory progress against this pest, though I have, through two seasons, tried about all the known remedies. Mr. Geo. E. Hartung of Sandusky, a market gardener, who has suffered much from the insect in former years, reports practically no injury this season, and believes his immunity was 
secured by overhead irrigation, since his neighbors suffered as in other years. Mr. Hartung's pipes are about 8 feet above the ground, 36 feet apart and the jets from the pipes are 4 feet apart. This result, and the attendant benefits of irrigation, seem to make this treatment worthy of testing by large market gardeners. For the ordinary kitchen garden, the most satisfactory treatment tried by me, from the view-point of good, healthy radishes, reasonably free from maggots, was a liberal application of tobacco dust every five or six days during the growing period, commencing as soon as the plants were through the ground.

The Hessian fly has dropped so nearly out of sight that careful search must be made to find it at all. I have not observed the chinch bug and only one or two correspondents have referred to it during the season. The wheat joint-worm has also decreased in numbers, not having been the subject of one half as many inquiries as were received regarding it last year.

The grape-berry worm has decreased considerably in the grape region along the lakes, but has become more injurious in the interior sections where the small, home vineyards are found. I repeated the experiments recorded in Circular 63, getting practically the same results. We used a traction sprayer fitted with 10 nozzles and throwing about 170 gallons of spray per acre. A double application with this machine-the Wallace-was very nearly equal to,thorough hand work. A check row that was sprayed three times with Bordeanx, containing no poison, had $58 \%$ of the berries wormy and yielded marketable fruit at the rate of 1,798 pounds per acre. One-half of this check row was sprayed during the latter part of July by hand, with arsenate of lead in Bordeanx, with a resin soap sticker added, and this half of the row had $2.9 \%$ of wormy berries and yielded marketable grapes at the rate of 5,608 pounds per acre. This plot had the lowest percentage of wormy berries of any in the tests, but lost too many young grapes in the early part of the season to equal in total harvest some of the plots that received earlier applications of poison. This plot proved. however, that the late July spraying is the most important of all, and that the later broods of the worm must be killed or comparatively little benefit will be derived from the earlier applications. This result is a repetition of the experience of last season regarding late spraying. A plot, hand-sprayed three times with Bordeaux, arsenate of lead, and resin soap sticker, had 3\% of wormy berries and yielded at the rate of 6,031 pounds of marketable grapes per acre. The grapes of this plot had too much spray adhering to them at harvest time, and it will be necessary to sacrifice some grapes 
rather than to send them to market in this condition. A plot sprayed three times with the same ingredients, by the double machine plan, had $4.47 \%$ of wormy berries and yielded 6,067 pounds of marketable grapes per acre. Three sprayings of Bordeanx, with arsenate of lead and resin soap added to the second and third applications, double machine plan, gave $4.8 \%$ wormy berries and harvested 3,864 pounds of marketable grapes per acre. The same ingredients applied at the same time as in the preceding case, but with single machine instead of double machine application, gave $20.34 \%$ wormy berries and harvested 3,465 pounds of marketable grapes per acre.

The double machine applications, if made three times with soap stickers, gave almost as good results as hand sprayed plots and were more presentable for market. It is quite conceivable, however, that if little rain were to fall in late summer, grapes treated in this way might carry too much spray to be presentable in appearance or safe to use in large quantities at harvest time. One plot was treated with a Bordeaux made of $4 \frac{1}{2}$ pounds of copper sulphate, 3 pounds of iron sulphate and 6 pounds of lime, with 3 pounds of arsenate of lead added. This made a spray that had good sticking qualities and yet washed off quite readily by rain. Three sprayings, donble machine application, with this mixture, gave $10.18 \%$ wormy berries and 5,760 pounds of marketable grapes per acre. This treatment seemed quite satisfactory for the fruit, but threatened to eat the galvanizing from the iron wires supporting the vines, thus shortening their durability by more than half. Parasites are appearing freely over the infested vineyards and doubtless are contributing to the suppression of the worm.

The greenhouse white fly has become established in many greenhouses and we have a good many inquiries regarding the process of fumigation with hydrocyanic acid gas. The fall webworm was abundant last year, but has been much more numerous the present season. Park superintendents and many orchardists have been obliged to wage systematic warfare against it the past summer. The black walnut caterpillar, Datana integerrima, has been numerous for two seasons, and many trees are threatened with destruction by it, having been completely defoliated for two years in succession. The white-marked tussock moth has been extremely abundant in city parks and was the subject of many inquiries. Pimpla inquisitor has become numerous at Dayton, according to local observers, and the suppression of the tussock worms is expected in that city in a short time. The terrapin scale, Eulecanium nigrofasciatum, has been our most serious scale insect on maple trees for the past two seasons. The remedies usually recommended for this scale-namely kerosene emulsion and the lime- 
sulphur wash in winter-have not given very good results where tried by the Station.

A rather extensive test against the peach borer was tried in a young orchard, but partially failed to yield results because of the scarcity of borers, even on the check trees, and of course full returns cannot be had until spring. I decided, however, that the use of building paper, or other protectors of like character around the trees for a period sufficiently long to be of effectual use in preventing egg-laying, was more undesirable than injury by the borers, while various sticky and poisonous mixtures were of questionable utility. Mounding with earth seemed among the best remedies, but by all odds the most satisfactory treatment from the standpoint of the trees and borers combined, was tying tobacco stems loosely about the base of the trunk, and suspending them from a point about twelve or fifteen inches above the ground. Prof. Slingerland gave a very good report of this treatment several years ago, but did not specially emphasize the splendid tonic effect it exercises on the trees. This treatment seemed to more than pay for itself without any reference to the presence of borers, while at the same time it possessed good value in this respect.

In $1906 \mathrm{I}$ took advantage of the proffered services of $\mathrm{Mr}$. C. F. Harbison of Dayton, $O$., to conduct a coöperative experiment against the elm leaf-beetle. Acting under my instructions, Mr. Harbison banded some elm trees in early June with Thum's Tree Tanglefoot to prevent the larvir reaching the groumd when descending to pupate. Immediately above this sticky band was arranged a burlap band, beneath which the insects could shelter and pupate. The first count of the catch was made June 17 , and showed 200 insects in the Tanglefoot band, 124 beneath the burlap and 72, which had been dislodged, at the base of the tree and were unable to re-ascend. This made 396 in total.

A second examination made June 21, collected 417 ; a third, 599, and a fourth, 422, making 1,834 beetles, pupe and larve taken from one tree.

About July 24th, eight trees were banded and the totals taken during the four examinations amounted to 16,122 insects in various stages, mostly larve and pupa. The number under the burlap band that had pupated kept constantly increasing at each examination, indicating the importance of the burlap in connection with the Tanglefoot. The same experiment was repeated the past year and $\mathrm{Mr}$. Harbison reports a collection of 4,938 insects from three trees on the 9 th of August; again, on August 13th, 8,491 insects from four trees; and on August 22d, 4,653 insects from three trees, making 18,082 insects from ten trees. I do not understand from the report whether the bands 
were put on all of these trees on the same date or not, but this is my inference. Mischievous persons, presumably boys, removed the bands before further examinations could be made, but we regard this method of fighting the insect as proved to be cheap and effective.

A Millipede, one of the Polydesmidee, became very numerous in the Station greenhouse this fall, occurring by tens of thousands in a bed devoted to forcing cucumbers. A few vines were killed before the insects attracted notice. The men in charge used a plentiful supply of tobacco dust as a mulch about the bases of the vines, and also mixed more or less of the dust in the soil, with the result that hundreds of dead worms could be found at the base of each vine a few days after the application was made, and tens of thousands of them dropped from the beds to the stone floor beneath, where they died. This remedy was a speedy and complete success.

In my bulletin on insecticides, published by the Florida station, I mentioned the use of powdered cyanide of potassium for ants, in cases where carbon bisulphide could not be conveniently used. This has been used so successfully by some parties to whom I have recommended it the past summer, that I think it worth while to emphasize the value of the treatment. The crushed cyanide must not come in contact with plant tissues, but should be sprinkled on the soil where the ants congregate, or have their nests. The ants either leave at once or attempt to remove the obnoxious particles, only to die in the attempt. The cyanide, if used in moderation, will act as a fertilizer for the plant and benefit instead of harming the same.

The Rosebug was abundant at Wooster, as has been the case for the past three seasons, and the vilest sprays do but little good against it. I have succeeded in driving them away for a day or two by spraying with Bordeaux mixture, to which was added arsenate of lead, fish-oil soap and crude carbolic acid, but they were always ready to return after a few hours' interval. The larger the area sprayed, the less heed do they seem to give the treatment. I found it practicable to fence them out from a few blooming grapevines with a covering of mosquito bar, and also that they conld be prevented from accumulating and doing any great amount of injury by picking them by hand three times a day through a two weeks' period. Though the latter method was only tried on a small scale, I am inclined to think it would pay in commercial vineyards of small size, at least in seasons where fruit is as high priced as at present.

During the spring, wheat and oats over Ohio suffered from a peculiar disease, marked by a reddening, yellowing and browning of the leaves, and a general stunting of the growth and retardation of the 
development in all respects. From the fact that the grain louse, Macrosiphum granaria, was noticed in considerable numbers in some fields, the newspapers and many correspondents attributed the damage to the lice. Others suspected thrips of causing the mischief. After an examination which I deemed adequate, I concluded that neither of these insects was primarily responsible for the disease so far as Ohio was concerned, though both species added to the trouble to a considerable degree in some fields. The majority of the diseased plants, however, were damaged but little by either insect, and many of them not at all, so far as I could determine. Corn, clover, alfalfa, strawberries and many weeds suffered in precisely the same way, as inferred from their external symptoms, and no insects whatever could be found upon them. I decided the trouble was probably wholly physiological in character, and was in all likelihood caused by the cold, wet spring. Parasites overtook the lice in most localities before they became excessively plentiful.

\section{THE HONEY AND POLLEN-YIELDING PLANTS OF TEXAS.}

By A. F. Coxiant, Clemson Collegr, S. C.

Triple-leafed Barberry. (Berberis trifoliata Moric.) On gravelly hills from the Gulf coast to the Limpia mountains. Yields honey abundantly, also pollen. Blooms January and February and is im. portant for early brood rearing.

Priekly Poppy. (Argemone platyecress link and Otto.) Abundant along roadsides, in waste fields and on prairies. Honey yield unimportant, but yields abundant pollen during dearth of summer. In the Brazos River Valley bees work heavily on it during June. The orange-colored pollen is carried to the hive, making the combs look disagreeable. MIay to July.

Poppy. (Papacer rhocas L.) Honey yield unimportant owing to scarcity of plants. May.

Pepper wort. Pepper grass. (Lcpidium virginicum L.) Widely distributed. Yields small quantities of honey and pollen.

Gregrgia. (Greggia comparum Gray.) Confined largely to west Texas. Blooms near San Antonio in February. Yields some honey, but pollen is important for early brood rearing.

Turnip. (Brassica rapa L.) Yields honey and pollen.

Black mustard. (Brassica nigra (L.) Loch.) Scatteringly throughout Texas. Bees work on it busily, but its status as a bee forage plant has not been determined. June and July. 